\title{
Exploration on the Construction of College Students' Innovation and Entrepreneurship Education Model
}

\author{
Rongxin Lv \\ Innovation and Entrepreneurship College, Shenyang Aerospace University, \\ Shenyang, Liaoning, China
} Keywords: Change the economic mode; Innovation and entrepreneurship; Educational model;
Research

\begin{abstract}
We live in an era of post-industrial or knowledge-based economy based on knowledge, information and technology, driven by innovation and entrepreneurship. The rise of the knowledge economy not only requires new modes of production, but also requires people to adapt to new modes of production, which in turn has a profound impact on education. The so-called new mode of production refers to production that is mainly driven by endless "innovation", and it is relative to resource-driven. This paper will use "knowledge-based entrepreneurship" as an intermediary to closely link the two. That is, the drive of innovation requires knowledge groups to devote themselves to the process of knowledge-based entrepreneurship. At the same time, innovation and entrepreneurship education needs to focus on knowledge-based entrepreneurship to organize and design educational content, modes, and methods. This shows the inevitable requirements and significance of innovation and entrepreneurship education in colleges and universities in the context of transforming the mode of economic development.
\end{abstract}

\section{Introduction}

In a era of knowledge economy based on knowledge, information and technology and driven by innovation, the knowledge economy has had a profound impact on the way of economic development, the direction of educational reform, the concept and model of talent cultivation, and the development of human beings. Innovation and entrepreneurship education came into being under this background. Innovation and entrepreneurship education is in line with the trend of the times and is consistent with the mainstream spirit of the times. It is a teaching philosophy and model that is adapted to the needs of economic society and national development strategy, and is a new confirmation and new response of the national development strategy in the field of education. It is the fundamental goal of how to cultivate the educator's innovative spirit and entrepreneurial ability. It is a new educational concept and practice of educational reform and is becoming a highlight of higher education innovation. This paper studies the theoretical issues related to innovation and entrepreneurship education in the context of transforming the mode of economic development. It studies the current situation, existing problems and causes of innovation and entrepreneurship education in colleges and universities; studies how innovation and entrepreneurship education utilizes regional resource advantages; and studies adaptation to economic development. The implementing countermeasures of innovation and entrepreneurship education in colleges and universities requirement of mode transformation.

\section{The Concept of Innovation and Entrepreneurship Education}

In the definition of innovation and entrepreneurship education, different objects and focuses can produce different understandings. This paper, after reading the literature and thinking and analyzing, divides the concept of innovation and entrepreneurship education mentioned by scholars into four types.

First, in order to highlight the important role of innovation education in entrepreneurship education, we will promote "students' innovative entrepreneurship" through education, that is, to cultivate students' innovative spirit, innovative techniques, innovative thinking, entrepreneurial 
awareness, entrepreneurial ability and entrepreneurial skills. Based on the content, the students' innovation and entrepreneurial behavior will be finally formed and the economic benefits will be achieved.

Second, because the development of entrepreneurship education is still at an exploratory stage, it still focuses on the traditional classroom teaching style. There is no grasp of the uniqueness of entrepreneurship education, the lack of practical reforms and innovations. In order to explore new methods and models for effective education, "innovative entrepreneurship education" points to the innovation of colleges, teachers, and courses and so on. The image is described as the internal entrepreneurship of colleges and universities.

Third, innovative education is proposed and implemented earlier than entrepreneurial education. Entrepreneurship education will become a hot issue in the future. To prevent entrepreneurship education, innovation education will be lost, and "prominent education will be emphasized and innovation education will be taken into account".

Fourth, innovation education and entrepreneurship education will become the focus and mainstream of future education, and the two are inseparable overall. It is necessary to form a situation of "combining innovation with one hand and entrepreneurship with one hand, while focusing on integrating with students' majors".

\section{Characteristics of College Students' Innovation and Entrepreneurship Education Adapting to Transforming Economic Development Mode}

\section{The Education of Innovative Entrepreneurial Concept Precedes the Education Of Innovative Entrepreneurial Behavior.}

The content structure of innovation and entrepreneurship education is entrepreneurial ideas and entrepreneurial behavior. Changing this background of the economic development approach requires more outstanding college students than college students with employment difficulties to venture into the business. It is not in this context that innovation and entrepreneurship education is carried out solely to solve employment problems. Now more outstanding university students are needed to innovation and entrepreneurship. At the same time, it gives meaning to the behavior of starting a business and encourages the best students to join in innovation and entrepreneurship. For example, innovation and entrepreneurship are glorious and morally mutually beneficial; entrepreneurs are innovators rather than capitalists, innovation and entrepreneurship profit from innovation surplus, not exploitation of surplus; entrepreneurs are the backbone of social and economic development; innovation and entrepreneurship is the individual comprehensive development and self-realization of the road.

\section{Innovation and Entrepreneurship Education Aimed at Knowledge-Based Innovation and Entrepreneurship.}

The main content of innovation and entrepreneurship education is innovation and entrepreneurship education with the goal of knowledge-based innovation and entrepreneurship. Based on the nature and characteristics of innovation and entrepreneurship, the concept of knowledge-based entrepreneurship and the subject of commitment are knowledge workers. That is, undergraduate students and knowledge-based entrepreneurship are innovation-based creative thinking training. The entire process is also the absorption, aggregation and condensation of innovation capabilities. The cohesion of innovation ability is likely to benefit from a series of exogenous factors such as demand conditions, corporate decisions, and production factors. But the core endogenous variables are the absorption of industrial knowledge and its ability to innovate and innovate.

\section{Based on Self-Realization as the Goal of Innovation and Entrepreneurship Education}

The basic goal of innovation and entrepreneurship education is to achieve full coverage, level and differentiation, and education for all students to achieve self-fulfillment. It is necessary to carry out innovation and entrepreneurship education for all students to improve students' innovative awareness, entrepreneurial spirit and practical ability; to personalize the students with the desire for innovation and entrepreneurship, and to enhance students' practical skills in entrepreneurial 
ventures; fully integrate with professional education and give full play to the advantages of students' practical skills in entrepreneurial ventures, in order to realize the self-worth of students under the parallel operating mechanism of "professional" education and "universal education".

It is an Education Model for all Students, Combined with Professional Education, and Integrated into the Entire Process of Personnel Training.

The basic requirements and practice model of innovation and entrepreneurship education are "education models for all students, combined with professional education, and integrated into the entire process of personnel training." Innovation and entrepreneurship education did not need to undertake the task of preaching - to inculcate particular values that are consistent or dissociated with social forces.

\section{The Significance of Developing Innovative and Entrepreneurial Education in Chinese Universities}

Facilitate the Development of a Knowledge-Based Economy and the Transformation of the Social Economy

Knowledge economy replaces labor, capital, land, raw materials and other primitive resources by knowledge and science and technology information and becomes a driving force with innovative power. It is a far-reaching social revolution in the era of the industrial revolution centered on the production of natural resources. The core issue is how to maximize human innovation potential. However, the improvement of knowledge will inevitably promote economic development. The promotion of knowledge is an important foundation for cultivating high-quality innovative talents. This kind of high-quality, compound, and innovative talent is a comprehensive development talent with a strong sense of innovation and spirit, practical training and practical ability, innovation and entrepreneurship.

Helping to Improve the Overall Quality of the People and Deepening Education Reform

Only by elevating the quality of the entire people and realizing the deepening reforms in China's education can we be truly compatible with the advancement of science and technology and the development of the market economy in the era of knowledge-based economy, so as to meet the development of the knowledge-based economy and the gradual improvement of the market economic system. More and more people are demanding. Innovation and entrepreneurship education is a kind of innovation and awakening in terms of content and form of traditional education and traditional employment education.

\section{Helping to Promote and Support Regional Economic Development}

The promotion and implementation of innovation and entrepreneurship education in Western developed countries and the exploration and creation of innovative and entrepreneurial talents are important internal driving forces for the rapid development of social economy in the West. It also plays an unpredictable driving role and strength support for regional economic development. The economy of each region of the country is surrounded by its characteristic industries and advantageous industries. Innovative entrepreneurs have created unprecedented wealth in the development of their regional economies. The quality of the innovative entrepreneurs themselves, the level of their talents, and the number of entrepreneurs determine the speed and quality of social and economic development, determine the long-term and coordinated development of the regional economy, and determine the rate at which the number of newly-established enterprises grows.

\section{Research on Innovation and Entrepreneurship Education Model}

Establish a Social Fashion of Innovation and Creation and Promote the Value and Spirit of College Students' Innovation and Entrepreneurship

The healthy development of innovation and entrepreneurship education in colleges and universities requires the advocacy of innovation and entrepreneurship, inclusiveness for frustration, critical judging, and accurate assessment of the social environment in which entrepreneurs live. In the external environment of innovation and entrepreneurship education in colleges and universities, 
although the social environment is not obvious, it is often intangible and can be found everywhere. It is an element that can have extremely far-reaching effects. Such elements contain many aspects such as the ethics of science and technology, social public opinion, psychological state, and social trends. The healthy development of colleges and universities in innovation and entrepreneurship education requires not only the advocacy of innovation and creation, the competition and expansion of public opinion guidance, but also the importance of practical experience. And more needs the participation of basic education. The government should rely on media from all walks of life to step up efforts to promote entrepreneurial-related content, and gradually create an atmosphere of public opinion that encourages and tolerates educated individuals to start their own businesses and establish criteria for jud ging the value of social subjects.

Fully Understand the Importance of Constructing a Complete Social Environment for Developing Innovation and Entrepreneurship Education

The social environment for the healthy development of innovation and entrepreneurship education is multifaceted, such as the improvement of social security systems and the guarantee of venture capital. The first is to standardize and create venture capital funds and venture capital funds. In particular, a variety of forms of college student start-up funds are created according to the actual situation, and appropriate institutional arrangements are made for college students to provide small-sum loan guarantees for self-employment. In the end, it created a diversified financing channel for innovative venture capital, built an innovative venture capital system and gradually improved the system. The second is based on the current status of college graduates' entrepreneurship, labor and social security and other relevant departments should incorporate the situation of college graduates into social unemployment and other related security management systems.

It is necessary to build a comprehensive social security system that covers the whole society, multi-levels, and a unified, detailed and complete system. Moreover, China should learn from the successful experiences of western developed countries, reduce the psychological cost and opportunity cost of college students' entrepreneurship, and reduce unemployment discrimination, and create related systems such as unemployment insurance. In Western developed countries, the development of innovation and entrepreneurship education has matured. These countries have a perfect social security system, equal and comprehensive protection objects and content, and these are their common characteristics. From this we can see that to achieve the entrepreneurial entrepreneurial psychological cost of continuous weakening, the cost of entrepreneurial opportunities and social employment discrimination changes, we must have a sound social security system, it is also an important institutional support for the healthy development of college entrepreneurship education and fundamental Guarantee.

Improve Related Laws and Policies to Smooth the Practice and Implementation of College Students' Innovation and Entrepreneurship

We must be good at translating education issues into education policies and solving many problems in innovation and entrepreneurship education. Our government departments and education-related departments attach great importance to college innovation and entrepreneurship education. We must promptly and decisively seize the opportunity to solve problems, and take effective measures to formulate them. The relevant policies and regulations have played a huge role in promoting the development of China's innovation and entrepreneurship education.

Laws, regulations, and related regulations play a regulatory, guiding, and leading role in college students' entrepreneurship. One of the main components of college students' entrepreneurial environment is legal protection. With the expansion of enrollment in colleges and universities for ten years, the pressure on employment has also increased year by year. In the course of innovation and entrepreneurship of existing college students, the awareness of legal protection of innovation and entrepreneurship is not strong, legal issues of innovation and venture capital financing are not clear, and innovation and entrepreneurship cannot be honored. From the policies and other issues, it can be seen that the legal environment for college students' innovation and entrepreneurship is still not sound enough and needs to be perfected and optimized. 


\section{Summary}

The innovation and entrepreneurship education in colleges and universities should be based on raising students' sense of social responsibility as the core; value-oriented with comprehensive and free development, and innovation skills (market or business innovation, technical innovation) as the skills basis; and the spirit of cooperation, innovation, and dedication; taking a systematic and comprehensive education system as a means to transform itself into an entrepreneurial university as a goal; as a guarantee of a system of innovation and entrepreneurship education; and actively serving the development of the regional economy and society. In the end, an ideal model for innovation and entrepreneurship education that maximizes the output of innovative entrepreneurial talents is established-a government-led, school-based, society-based platform, and knowledge-based entrepreneurship are the main forms of innovation and entrepreneurship education.

\section{References}

[1] Yang K. Present situation and countermeasures of university students' innovation and entrepreneurship education[J]. Journal of Nanchang College of Education , 2011.

[2] Harkema S, Schout $\mathrm{H}$. Incorporating student-centered learning in innovation and entrepreneurship education[J]. IEEE Engineering Management Review, 2012, 40(2):164-174.

[3] Mei Y, Feng H, Ye L U. Practice of Our Library Characteristic Information Service under the Innovation and Entrepreneurship Education Perspective[J]. Journal of Library \& Information Sciences in Agriculture, 2012.

[4] Guo M. Innovation and Entrepreneurship Education in Colleges Based on Economic Transformation and Upgrading[J]. Modern Education Management, 2014.

[5] You M, Zhu F, Deng A. Analysis of the Hierarchical Classification Model of Innovation and Entrepreneurship Education in Universities from the Perspective of Typology[J]. Journal of Chongqing University of Posts \& Telecommunications, 2014.

[6] Weng F, Ke L, Ding M, et al. On Innovation and Entrepreneurship Education in Colleges and Universities of Traditional Chinese Medicine[J]. Journal of College Advisor, 2015.

[7] Song L J, Jiang R. The Optimization of Innovation and Entrepreneurship Education for Private HEIs:The Case of Jiangxi Institute of Fashion Technology[J]. Fudan Education Forum, 2015.

[8] Gao K, Hua J, University D J. Study on the Innovation and Entrepreneurship Education Evaluation Based on Improved AHP Method[J]. Modern Education Management, 2015.

[9] Liao C L, Polytechnic S. Exploration of Innovation and Entrepreneurship Education Based on the Promotion of College Students' employment Ability[J]. Education Teaching Forum, 2016.

[10] Yi Y U. Research on Innovation and Entrepreneurship Education in Higher Vocational Colleges under the Background of "Internet +"[J]. Agriculture Network Information, 2016.

[11] Yong L I, Lei Y, Gao H T, et al. Research on the Role of Internet in Innovation and Entrepreneurship Education[J]. Modern Computer, 2017.

[12] Wang Y. A Study on Construction of Innovation and Entrepreneurship Education Curriculum System of Tourism Management in Universities[C]// International Conference on Education, Management, Computer and Medicine. 2017.

[13] Huang Z J, University F S. Research on the Role of College Communist Youth League in Promoting Innovation and Entrepreneurship Education for College Students[J]. Journal of Hubei Correspondence University, 2017.

[14] Guo K T. The Probe of Practice Teaching Model of Pressed Flower Art Course Oriented to Innovation and Entrepreneurship Education[J]. Journal of Anhui Agricultural Sciences, 2018. 